\title{
Distopya Romanlarının Oluşumu ve Tarihsel gelişimi; Çevirilerinin İncelenmesinde Öne Çıkan Kuramsal Yaklaşımlar
}

\section{Formation and Historical Development of Dystopian Novels: Prominent Theoretical Approaches in Translating Dystopian Novels}

\author{
Necdet Neydim $^{1} \oplus$, Ali Polatel ${ }^{1}$
}

1'stanbul Üniversitesi, Edebiyat Fakültesi, Çeviribilim Bölümü, İstanbul, Türkiye

ORCID: N.N. 0000-0002-0777-1399; A.P. $0000-0003-1704-5937$

Sorumlu yazar/Corresponding author: Necdet Neydim (Doç. Dr.),

İstanbul Üniversitesi, Edebiyat Fakültesi, Çeviribilim Bölümü, İstanbul, Türkiye

E-posta: neydim@istanbul.edu.tr

Başvuru/Submitted: 05.05.2019

Kabul/Accepted: 20.06.2020

Atıf/Citation: Neydim, N. ve Polatel, A. (2020). Distopya romanlarının oluşumu ve tarihsel gelișimi; Çevirilerinin incelenmesinde öne çıkan kuramsal yaklaşımlar. Istanbul Üniversitesi Çeviribilim Dergisi - Istanbul University Journal of Translation Studies 12, (2020), 53-75. https://doi.org/10.26650/iujts.2020.12.0004

\section{öz}

Distopya yazını, ütopyaya karşıt bir tutum sergilemiş ve bir yazın türü olarak ütopya türüyle kurduğu metinlerarası ilişkilerle evrilmiş ve yirminci yüzyılda kendi çerçevesini belirleyerek özgün bir yazın türü haline gelmiştir. Söylem düzleminde ütopyaya karşıtlığıyla kendini tanımlayan ve gerekçelendiren distopya, ütopyaların gerçek topluma yönelttiği eleştirileri de kendisine miras olarak almıştır. Ütopya yazınının tarihsel evrimine baktığımızda özellikle klasik ütopya eserlerinde öne çıkan ada kavramıyla karşılaşırız. Ütopya yazarı, kurgu düzenini gerçek düzenden soyutlayarak gerçek toplum düzenine karşı bir tür yabancılaşma sağlar. Böylelikle düzeninin aksayan yönlerini ve eniyileşme yolunda yapılması gerekenleri önyargısız, dışarıdan bakan bir gözle betimleyebilir. Distopya yazını, ütopyaların aksine, soyutlamayı gerçekten yabancılaşmak için değil kendini gerçek ile gerekçelendirmek için kullanır. Çevirmenin kaynak metin yazarının yönelttiği toplum eleştirisiyle ideolojik bağlamda kurduğu ilişki çevirmenin görünmezliğiyle bir karşıtlık yaratarak çevirmeni, deyim yerindeyse, su yüzüne çıkmaya zorlamaktadır. Çeviri incelemelerinde bu tür karşıtlıkların varlığı çeviri eleştirmenleri ve araştırmacıları için verimli bir zemin oluşturur. Çevirmenin görünmezliği ile ideolojik söylem arasındaki karşıtlık, çevirmenin çeviri süreci boyunca aldığı bilinçli kararların ve çeviri sürecine hakim olan eğilimlerin saptanması ve anlamlandırılması açısından önemlidir.

Anahtar kelimeler: Distopya, Distopya tarihi, Distopya eleştirisi, Distopya çevirisi, Çeviri yaklaşımları, Çeviri kuramları

\section{ABSTRACT}

Dystopian literature emerged as a response to utopia, evolved as a result of its intertextual relation to utopian literature and became a distinctive genre in the twentieth century. Dystopia, which defines and justifies itself with its opposition to utopia, has inherited the utopia's criticisms for the society. If we look at the history of the utopian literature, we see that the "island" is a common concept. The author of the utopian literature creates an alienation from social order by isolating the fiction from the reality. Therefore, the author can demonstrate in 
an unbiased way the flaws of the social order, and can describe what should be done for a perfect society. Dystopian literature, in opposition to utopia, uses isolation in order to justify itself with the reality, not for alienation. The translator's ideological connection to the author with his/her criticism to the author creates a contradiction with the translator's invisibility, and forces the translator to become visible. The presence of such contradictions forms a fruitful basis for the translation critics and researchers. The contradiction between the translator's invisibility and the ideological discourse is important in order to determine the translator's decisions in the translation process and the trends that dominate the translation process and to make sense of these trends.

Keywords: Dystopia, history of dystopia, criticism of dystopia, translation theories, approaches to translation 


\section{Tanım Gelişim ve Artalan}

Distopya denince en kötü şekilde oluşturulmuş bir toplum düzeni söz konusudur. O toplumda yaşayan bireylerin erk sahipleri tarafından kölece kullanıldığı birey olmanın, özneliğin, özgür düşüncenin olmadığı; işkence, baskı, sansür gibi araçların sınırsızca kullanıldığı bir sistemden söz edilir. İlginç olan, bu sürecin, ütopya gerçekleştirmek üzere başlanmış olması; ama her şeyin ters gitmesiyle oluşmasıdır. Hayalin kabusa dönüşmesi söz konusudur.

Distopya ütopyanın kendi iç sorunlarını görünür kılma çabasındadır, bu çabanın ona karşı çıkmak olarak algılanması doğru değildir. Bir düş olarak tanımlayabileceğimiz ütopyaya karşılık distopya kabustur denilebilir. Ayrıca bu iki alanın varlığı doğası gereğidir. Ütopya olmadan distopya olmaz. Birbirlerinin varlık nedenidirler.

\section{Distopya Kavramı, Tanımı ve Çerçevesi}

Ütopya kavram olarak kusursuzluk anlamı içerir ve bu özelliği onu gerçek dünyadan mutlak biçimde ayırır. Bu bağlamda baktığımızda ütopyayı kurgulayan, kusursuz bir toplumsal düzen var etmeye çalışırken bir yanıyla geçmişe diğer yanıyla geleceğe dönük bir bakış açısıyla davranır.

Ütopya kurgulayanın geçmişte düşlediği mutluluğu bulması söz konusu değildir. Bu nedenle onun geleceğe yönelmesi düşlerini geleceğin ufkuna ilerlemenin sonsuzluğuna yerleştirir.

Mannheim, ideoloji ve ütopya ayrımını yaparken aynı zamanda ütopyanın neden geleceğe yerleştirilmesi gerektiğini de nedenlendirir. İdeolojinin geçmişte yer aldığını ve o zaman diliminde net biçimde tanımlandığı belirlenmişliğinden yola çıkarak değişmezliğini söylerken, insanın ve dünyanın durağan olmadığını ve sürekli değişim geçirdiğini ifade eder. Bu nedenle ideoloji ve ütopyanın uyumlu olması beklenemez. Çünkü ütopya bugünden geleceğe bakmak anlamına gelir. İdeoloji geçmişten şimdiye bakarken ütopya şimdiden geleceğe bakar. Mannheim bunu "gerçeğin aşkınlaştırıcı işlevi” olarak tanımlar (Mannheim: 2009, 187).

Genel anlamda ütopya kavramına getirilen eleştiriler aynı zamanda distopyanın tanımlanmasında işlevsel bir rol oynar. 19. Yüzyılda başlayıp 20. yüzyılda gerçekleşme aşamasına geçen ideolojiler özellikle Hitler Almanya’sı ve Stalin'in hükmettiği Sovyetler Birliği yönetimlerinin uyguladıkları ütopyacı söylemlere bakıldığında kendi iktidarlarını kabul ettirmede her türlü söylemin masumiyet perdesine bürünerek kabul ettirilmeye çalışıldığını görmek mümkündür.

Çörekçioğlu, ütopyayı eleştirenlerin bu düşünceyi çürütmek için üç temel kanıtı öne sürdüğünü söyler. Ütopyaya ilişkin olan “sonsal amaç”ın “fikri özcülüğe” gönderme yaptığının altını çizen Çörekçioğlu (1994:37) bu kanıtların mantıksal altyapısını şöyle açıklar:

Özcü anlayışı ele aldığımızda bu anlayışın hedefe varmada her türlü aracı kullanmanın meşru olduğuna inandığını söyleyebiliriz. Buradan yola çıktığımızda ütopyacı düşüncenin özcü bir yaklaşım olduğu ve nihai olarak baskı ve şiddetle sonuçlanacağı gerçeğine ulaşırız.

İdeal olan tanımı gereği mükemmel olmak zorundadır. Buradan da ikinci anti-ütopyacı kanıt çıkar: Mükemmellik fikri, hem değişime kapalı, yani tarihi ve gelişmeyi tamamen donduran, durağan bir toplumun inşasıyla sonuçlanır hem de her türlü bireyselliği ve farklılı̆̆ 
eşitlik adı altında yok eden toplumsal uyum fikrine götürür. Nihayet bu iki kanıtın kaçınılmaz sonucu olan üçüncü anti-ütopyacı kanıta ulaşırız: Ütopyacı düşünce ile özgürlük birbiriyle uzlaşamaz. Böylece anti-ütopyacı akıl yürütmenin döngüsü tamamlanır. Ütopyacılık her durumda, gerçekleşmesi imkansız olan, gerçekleştirilmeye teşebbüs edildiğinde baskı ve şiddetle ya da totalitarizmle sonuçlanan bir düşünme biçimidir (Çörekçioğlu, a.g.e: 37).

Çörekçioğlu'nun özetlediği bu gerekçelendirme, ütopya karşıtı düşünürlerin önde gelenlerinden olan liberal Anglo Sakson deneyimci geleneğin temsilcilerinden Karl Popper'in Açık Toplum ve Düşmanları eserinde (bkz. Popper, 1994) yaptığı ütopya çözümlemesi ve beraberinde getirdiği ütopya eleştirisinin bir özeti niteliğindedir. Popper, ütopyacı düşüncenin tarihsel sürecini izlediği çözümlemesinde Platon'dan başlayarak günümüze gelen ütopya kavramına içkin olan yetkeci tutumu sorgular. Popper'ın eleştirisinin odak noktasında kusursuz düzeni inşa eden ve sürdürülmesini sağlayan araç ve öznelerin Popper'a göre kusursuz olmayan yapıları vardır. Örneğin, Platon'un Devlet'inde yönetici sınıf olarak filozofların seçilmesini sorgulayan Popper (a.g.e: 144), Platon'un böylelikle filozof terimine "tanrılık Formlar ya da İdealar dünyasının aşı̆̆ı ve gözlemcisi” şeklinde yeni, dogmatik bir anlam yüklediğinin altını çizer: "Model diye tanrılık olanı almış" filozofun bilimsellikten ve nesnellikten uzaklaştığı bu bağlamda Popper'a göre kuşku götürmezdir.

Amacın aracı yasallaştırmasının kanıtı, ütopya karşıtı eleştirinin temelini oluşturur. Kusursuz toplumsal düzene atfedilen yüce nitelik, bu düzenin kurulması yolunda kullanılan araçlara içkin olan olası kötülükleri gizleyici, masumlaştırıcı bir işleve sahiptir. Amaç-araç arasındaki ilişkiyi iyi-kötü ayrımına indirgeyen ve böylelikle iyi olabilmek için kötü olmak fikrine gerekliliğiyle eşdeğer bir masumiyet atfeden ütopyacı düşüncenin mantıksız olduğunu savlayan bu kanıt, çalışma konusunu oluşturan George Orwell'in distopyası 1984'ün enkötüleştirilmiş toplumsal düzeninde - "yalnızca güç için güç" sloganıyla - kötü aracın evrilmesi ve nihai kötü amaca dönüşmesi üzerine inşa edilen sürecin altyapısını oluşturan unsur olacaktır. Ütopyacı düşünce, kusursuz toplumsal düzenin gerçekleştirilebilirliğini temel iddia olarak alır. Böylece toplum kavramına kendisini oluşturan bireylerden daha üstün bir değer biçer. Ütopya düzenlerini betimlemek için düzene dışarıdan bakabilen, yabancı özneler anlatıcı olarak seçilir ve kurgu boyunca konulaştırılan temel öğe hep toplumdur. Toplumu oluşturan bireyler yalnızca kurucu kral, yönetici bilim insanı vbg. toplumu kurucu, eniyileştirici ve sürdürücü rolleriyle ütopya kurgusu içinde bir yer edinirler. Bireyler, böylelikle kişiliklerinin kusursuz topluma fayda sağlayan unsurlarına indirgenmiş olur. Kusursuz toplum içinde toplumdan bağımsız bir bireyselliğe yer yoktur. Ütopya eleştirisinin diğer bir temelini de bu toplum-birey ayrımı ve toplumun kusursuzlaşırken bireyi toplumu oluşturan niteliklerine indirgeyen tutumunun yarattığı çatışma oluşturur.

Ruhçözümcü kuramın kurucusu Freud, uygarlığın kusursuzlaşma sürecinde kendini oluşturan bireylerin sözüm ona kusurlu yönlerini bastırma gereksinimini, kusursuz toplumsal düzenin gerçekleştirilebilirliği savını çürüttüğü görüşündedir. Uygarlığın Huzursuzluğu adlı eserinde 
bireyin mutluluğunun önündeki engelleri çözümleyen Freud (2011: 45), bireyin acılarının üç temel kaynağını "doğanın üstün gücü, kendi bedenimizin zayıflığı ve insanların aile, devlet ve toplum içinde birbirleriyle ilişkilerini düzenleyen ayarlamaların yetersizliği” olarak sıralar. Bunların ilk ikisinin bireyler için görece kolay kabullenilebilir olduğunun altını çizen Freud, bu kabullenişin de insanın elini kolunu bağlamak yerine onun yapacaklarına yön verdiğini ifade eder. Freud'a (a.e: 45) göre insana acı veren kaynakların üçüncüsü olan toplumsal acı kaynağına bireylerin takındığı tutum bireyin diğer iki acı kaynağına bakışına karşıt niteliktedir: İnsan, toplumsal acı kaynağını kabullenmeye asla yanaşmaz ve uygarlığın neden "acı yerine koruma ve saadet kaynağı olamadığını anlayamaz”. Freud (a.e: 46), toplumsal acının özünde insanın doğaya hakim oluş çabasındaki imkansızlığı kabullenişine karşıt olarak insanın "kendi ruhsal bünyesi[nin] ...hakim olunamayacak doğası"nı reddedişinin yattığını savlar ve toplumun imkansız olan bu hakimiyet çabasıyla "kendi kültürel idealleri uyarınca bireye dayattığı engellemelerin çekilmez hale gelmesinin bireyi nevrotikleştirdiğini” vurgular. Böylelikle uygarlık, cinsellik vb. dürtüleri baskılayan bir üstben işlevi görür.

Kusursuz toplumun birey ile olan çatışması, distopya yazınında enkötüleştirilmiş toplum düzenlerinin bireysel özgürlük karşıtı tutumlarının altyapısını oluşturur. Distopya yazınının önde gelen eserlerinde bu bağlamda cinselliğin baskılanması ve devlet denetimine girmesi temasına çokça rastlarız: Aldous Huxley’nin Cesur Yeni Dünyası'nda seri insan üretimi Kuluçka ve Şartlandırma Merkezi adıyla kurumsallaşmıştır; Yevgeniy Zamyatin'in Biz'inde insanlar cinsel ilişkiye girmek için Seks Bürosu'ndan bir pembe bilet alarak ilişkiye girecekleri kişiyi ve saati belirlemek zorundalardır. George Orwell'in 1984'ünde de benzer şekilde cinsellik yalnızca üreme niteliğine ve toplumsal düzeni sürdürücü işle vine indirgenmiştir. Enkötüleştirilmiş toplum, toplum-birey çatışmasında toplumun koşulsuz yengisinin sonucudur: Birey, yetkeci toplum tarafindan bütünüyle sindirilmiştir. Distopya böylelikle toplumun cenneti olmayı hedefleyen ütopyanın bireyin cehennemine dönüşmesini konulaştırır.

\section{Distopya Yazını: Kısa Tarihçe}

Ütopya kavramına getirilen eleştiriler kavramın kendisi kadar eskidir. Ülkücü bir anlayışın ürünü olan kusursuzluk niteliği, karşıt şüpheci bir yaklaşımı güdülemiş ve ütopyacı düşünce ütopya karşıtı eleştiriyle birlikte gelişmiştir. Ütopya karşıtı eleştirinin kurgu dünyasındaki çehresi distopya yazınıdır. Ancak bir yazın türü olan distopya ile ütopya kavramına karşı şüpheci bir yaklaşım benimseyen ütopya karşıtı eleştiri arasında temel bir ayrım söz konusudur: Distopya kurgularının temelinde bir ütopya kurgusu yatmaktadır. Ütopyacı düşün kâbusa dönüşebilirliğini konulaştıran distopya yazını böylelikle ütopyayı çürütücü bir etkinlik olmaktan ziyade ütopyacı kusursuzluğun içinde masumlaştırılabilecek olası kötülüklere karşı uyarıcı bir tutum takınır. Klasik ütopya yazınından Swift' in Güliver'in Gezileri'ne geldiğimizde ütopya ile distopyanın birlikte varoluşunu incelemiş, distopyaya içkin olan ütopya varlığının altını çizmiştim: Kusursuz at toplumu Houyhnhnm'ler bir ütopyadır ve Yahoo insanlarının oluşturduğu toplum ise bir 
distopyadır. Yazar, bu enkötüleştirilmiş Yahoo toplumu üzerinden kendi zaman-uzamındaki toplumu eleştirme şansı bulur ve distopyanın varlığını eleştiriyi olanaklı kılan bu işlev ile sınırlar. Bu bağlamda eser, öncelediği distopya yazın türü eserlerinden ayrılır: Swift'de düş ile kâbus, ütopya ile distopya birlikte var olur; toplumsal düzen büsbütün kötü değildir ve metnin bir ütopya tasarısının gerçekleştirilmesiyle ortaya çıkabilecek olası kötü sonuçlara karşı bir uyarıcı niteliği yoktur.

Distopyanın kendine özgün niteliklere sahip bir yazın türüne evrimi yirminci yüzyılın başlarına rastlar. Yazın türüne içkin olan karamsarlığın kökenini dönemin siyasi yapısında ve ülkelerarası ilişkilerinde görmek mümkündür. Büyük imparatorluklar çöküşs sürecindedir ve yerküre iki büyük savaş ile yerle bir olmanın eşiğindedir. Teknolojinin gözbebeği olan makinelerin yaygınlaşmasının beraberinde getirdiği Sanayi Devrimi ve Avrupa devletlerinin yayılmacı dış siyasetlerinin sonucu ortaya çıkan Sömürgecilik toplumların sınıf yapılarında değişimlere yol açar: Seri üretim merkezleri olan fabrikalar, yüksek kâr elde etmek amacındadır. İşçiler düşük yevmiyeler için uzun mesai saatleri boyunca çalışmaktalardır. Çocukların işçi olarak çalışmasının önünde bir engel yoktur, aksine çocukların küçük yaşta çalışmaya başlaması teşvik edilmektedir. Kentsoylu sınıfının yeni üyesi olan fabrika sahipleri toplumların en zengin sınıfını oluşturmaktadır ve ortaklıklarıyla kurulan tröstler küçük işletmeleri sindirerek büyümekte ve tekelci anlayışlarıyla ülke yönetimlerinde de söz sahibi olma amacı gütmektedirler.

\section{İlk Distopya: Demir Ökçe}

Çağdaş distopyaların ilki olarak kabul edilen Jack London'un Demir Ökçe (bkz. London, 2006) adlı romanı ilk olarak 1908 yılında yayınlanmıştır. Metin, yönetim erkinin maddi açıdan üstün yöneticiler tarafından paylaşıldığ 1 enkötüleştirilmiş bir toplumsal düzeni konu alır. Sosyalist bir anlatıcının gözünden gün be gün zenginleşen ve böylelikle güçlenen varlıklı tröst ortaklarının yönetimde etkinleşmeleri konulaştırılır. Yönetimi ele geçiren zengin kentsoylu sınıfı ile giderek yoksullaşarak köleleşen işçi sınıfı arasındaki çatışma toplumun enkötüleşmesinin temelinde yatan kutuplaşmayı oluşturur. Yargı, basını ve kiliseyi etkisi altına alarak güçlenen kentsoylu sınıfı kendi ütopyasını kurarken anlatıcı, toplumun büyük bölümünü oluşturan işçi sınıfının adım adım köleleşmesine ve böylelikle toplumsal düzenin enkötüleşmesine tanıklık eder.

Zengin bir ailenin kızı olan anlatıcı Avis Everhard, romanın baş kahramanı devrimci Ernest Everhard ile evlenir. Eşinin markş̧ı görüşlerini benimseyerek sosyalist olur. Öncesinde kentsoylu sınıfın üyeleri olan Avis ve babası, Ernest'in hayatlarına girmesiyle kusursuz zannettikleri toplumsal düzenin "kan üzerine kurulmuş” (London, a.g.e: 90) olduğunu öğrenirler: Yaşadıkları ütopya, işçilerin oldukça düşük yevmiyelerle, insanlık dışı koşullarda ölesiye çalıştırılmaları sayesinde ancak ayakta durmaktadır.

Anlatıcının aralarına katıldığı sosyalist devrimcilerin Demir Ökçe adını taktığı London'un distopyasının baskıcı yönetimi, yargı, basın ve kiliseyi bütünüyle denetimi altında tutmaktadır. İş kazaları sonucu birçok işçi ölmekte, sakatlanmakta ve/ya da yaralanmaktadır ancak açılan hiçbir 
dava bu işçilerin lehine sonuçlanmamaktadır. Basın, kentsoylu sınıfın aleyhine olan haberleri yayınlamamakta ve gerçekleri olabildiğince bu sınıfın yararına olacak şekilde çarpıtmaktadır. Kilise, kentsoylu sınıftan aldığı bağışlara minnet duymakta ve çarpık düzene ses çıkarmamakta, aksine düzeni desteklemektedir. Enkötüleştirilmiş toplumsal düzen hakkındaki gerçekleri öğrenen anlatıcı-kahraman Avis, hayatını eşiyle birlikte sosyalist devrimci mücadeleye adar; yavaş yavaş tekelleşen ve güçlendikçe vahşileşen kentsoylu sınıfın işçi sınıfına uyguladığı baskı ve şiddeti anlatır.

Ütopyaların, bireyselliği toplum içinde eriterek sindirmesine karşı oluşan distopyacı tepkinin etkilerini London'un anlatıcısında görmek mümkündür: Anlatıcı, incelediğim ütopya yazını metinlerindeki anlatıcılara karşıt olarak konulaştırılan topluma yabancı bir özne değil, enkötüleştirilmiş toplumun bir üyesidir. Toplumsal dizge karşıtı karakter Ernest tarafından düşünden kâbusa uyandırılır ve böylelikle yaşadığı ütopyanın bir distopyaya olduğunun farkına varır. Uyandırıcı karakterin karşı cinsten oluşu, anlatıcının enkötüleştirilmiş toplumsal düzen tarafından baskılanan cinselliğinin uyanışını esinler. Böylece anlatıcı toplumdaki edilgen, tarafsız konumunu terk eder ve etken, dizge karşıtı bir rol üstlenir. Anlatıcının geçirdiği bu başkalaşım, distopya yazın türünde çokça kullanılan bir yabancılaştırma tekniğidir.

Ütopya yazınının distopya yazını üzerindeki etkilerine uyandırıcı karakterin enkötüleştirilmiş toplum karşıtı eylemlerinde de rastlamak mümkündür. Ernest, kentsoylu sınıfın üyeleriyle giriştiği tartışmalarda bu sınıfın gözündeki ütopya algısının bir yanılsama olduğunu kanıtlamaya girişir. Yazar bu tartışmaları ütopya yazınında çokça kullanılan söyleyiş biçiminde metne taşır ve eniyileştirilmiş sanılan toplumun savunucularının savlarını didaktik bir tavırla çürütmeyi amaçlar. Söyleyiş biçiminin kullanımı ve dizge karşıtı karakterin öğretici bir tutum benimsemesi böylelikle distopya anlatısını ütopya anlatısıyla yöntemsel olarak eşdeğer bir düzleme yerleştirerek ütopyayı sorgulayıcı şüpheci yaklaşımı odak noktasına alır.

London'un eseri, distopya yazın türüne özgün biçimsel ve biçemsel özellikleri yansıtması bakımından önemlidir. Distopya yazınının özelliklerini inceleyeceğimiz bölümde detaylıca irdeleyeceğim bu özellikler, deyim yerindeyse, bu yazın türünün karamsar ezgisini oluşturan öğelerdir ve distopya yazını çevirisi incelemelerine 1 şık tutan nitelikleri nedeniyle çalışmam için değerlidir. Demir Ökçe eserinde bu özelliklere verilebilecek uygun bir örnek metin boyunca süregelen dipnot kullanımıdır. Bu biçimsel özellik, metnin biçemsel yapısına ve zamansal kurgusuna katkı yapmak için kullanılır. Hikayenin sıfır zamanı 3 ampirik yazarın gerçek zamanıyla eştir: Hikayenin başlangıcı yirminci yüzyılın başlarıdır. Kentsoylu sınıf, ortak işletmeler kurarak güçlenmekte; adım adım yönetimi ele geçirmektedir. Dipnotlar ise metin boyunca anlatıcıdan farklı bir kişinin, örnek yazarın, ağzından konuşur; artgönderimler ile 2700'lü yıllardan hikaye zamanına bakar. Aradan geçen yüzyıllar sonrasında enkötüleştirilmiş düzen yıkılmış ve eniyileştirilmiş sosyalist bir düzen kurulmuştur.

Varlığı dipnotlarla sınırlı olan örnek yazar Anthony Meredith için ana metin geçmişin kara sayfaları niteliğindedir. Anlatıcı-kahramanın hayatını adadığı devrim mücadelesinin meyvesi olan İnsanlığın Kardeşliği adlı eniyileştirilmiş toplumda yaşayan bir bilim insanı olan örnek 
yazar, anlatıcının metin boyunca işbirlikçisi olur. Kimi zaman anlatıcı için ya da örnek okur için karanlıkta kalan noktalara açıklık getirir kimi zaman da anlatıcının kanıtlayamadığı, çoğunlukla kentsoylu sınıfın hasır altı edilen suçları hakkındaki şüphelerini doğrulayan kanıtlar sunar. Hikaye zamanında anlatıcı, eşi Ernest ve diğer devrimcilerin çabalarıyla denenen ancak başarısız olan Birinci Devrim'in öncelediği İkinci Devrim'den sonra gelen altın çağdan metne bakan örnek yazar, böylelikle enkötüleştirilmiş toplumunun gelecekteki adaletli yargıcı olur.

London'un Demir Ökçe'si distopya yazın türünün ütopya yazınından kendisine miras kalan biçimsel ve biçemsel özelliklerle distopyanın kendine özgü niteliklerinin harmanlandığı bir metindir. Çerçevesini yavaş yavaş belirlemekte olan distopya türü böylelikle ütopya türüyle kurduğu metin düzleminde koşut, söylem düzleminde ise karşıt olan ilişkilerden beslenerek gelişmekte ve kendini bir yazın türü olarak tanıtlama yolunda evrilmektedir. 3Hikayenin sıfır zamanı, kurgunun hareket noktasıdır. Bkz. Eco, 2003: 60

\section{Distopya Yazınının Evrimi}

London'un eserinin yayınlandığg 1908 yılından altı yıl sonra özellikle Avrupalı devletlerin yayılmacı siyasetlerinin sonucu patlak veren Avrupa merkezli küresel savaş, yerküreyi eşi görülmemiş bir yıkıma sürüklemiştir. Savaşın sonlandığg 1918 tarihinden bir yıl önce Rusya'da yaşanan Ekim Devrimi, savaşa İtilaf Devletleri'nin tarafında katılan Çarlık Rusyası'nın yıkılmasına yol açan bir iç savaşa neden olur. Beş yıl süren iç savaşın ardından 1922 yılında Rusya İmparatorluğu'nun yerine Sovyet Sosyalist Cumhuriyetler Birliği kurulur. Yirminci yüzyılın başlarında küresel savaşın yerküreyi sarsan derin etkileri,uygarlığın üzerine inşa edildiği temel taşların sorgulanmasına yol açar. Bilim ve teknoloji de bu sorgulama çerçevesinde konulaştırılmıştır. Yüzyıllarca insanlığın doğaya hükmedişinin ölçütü olarak görülen bilimin, teknolojinin gelişimini on sekizinci ve on dokuzuncu yüzyıllarda ivmelendirişiyle ortaya çıkan makineleşme sürecinin getirdiği Sanayi Devrimi’nin ardından teknolojinin insan refahını arttıran araçlar üretmesine koşut olarak devletlerin savaşlar kazanması için de gün be gün daha gelişkin yıkım araçları tasarlıyor oluşu bu sorgulamaların özünü oluşturur.

Makineleşmenin üretimi hızlandırıcı, artırıcı etkisinin giderek toplumsal yapıyı değiştirmesi distopya yazınında çokça konulaştııılan bir öğe olarak karşımıza çıkar. Bilimin kurgu dünyasına uzanan, insanların gelecek konusundaki önsezilerini ve düşlerini yansıtan bilim-kurgu türünün konulaştırdığı makinelerin insanlaşması teması bu noktada ütopyacı iyimserliğin distopyacı karamsarlığa dönüşümünü yansıtması bakımından dikkat çekicidir. 1920 yılında Çek yazar Karel Čapek tarafından kaleme alınan R.U.R. adlı tiyatro oyunu, makine-insan arası bir varlık olarak robot kavramını ilk defa ortaya atışı bakımından önemlidir. Somay’ın (a.g.e: 79, 80) ifade ettiği üzere oyunun adındaki kısaltmanın açılımı - Rosumovi Umělí Roboti - Rossum'un Akıllı Robotları anlamına gelmektedir ve "robot kelimesi Çekçe'de "işçi" anlamına gelen robotnik kelimesine gönderme yapan türenti bir kelimedir." Her ne kadar eser bir distopya olmasa da robotların "en iyi işçi en ucuz işçidir (Somay, a.g.e: 80)" alt metnine içkin olan 
göndergeyle işçi sınıfının yerini alması ve insan kavramının kentsoylu sınıfa indirgenmesini takiben oyunun sonunda robotların bir devrim ile yerküreyi ele geçirmeleri "Birinci Dünya Savaşı sonrası yaşanan devrimlerin etkileri (Somay, a.g.e: 80)" olarak yorumlanabilir.

Čapek'in eseri, Swift'de dikkatimizi çeken kurgu toplumda eşzamanlı yaşanan ütopya ve distopya teması bağlamında da dikkat çekicidir. Yirminci yüzyıla girilirken bu temanın işlendiği bir diğer eser Herbert George Wells'in ilk olarak 1895 yılında yayınlanan Zaman Makinesi (bkz. Wells, 2012) adlı bilimkurgu romanıdır. Wells, eserinde anlatıcının Zaman Gezgini olarak adlandırdığ seyahati anlatır. Kahraman öncelikle eniyileştirilmiş bir toplum olarak betimlenen küçük, güzel ve çocuksu insanlardan oluşan Eloi toplumu ile karşılaşır: Yeryüzü cenneti kurgusunu, çalışmak zorunda olmayan bu toplumda görmek mümkündür. Kahraman, böylelikle yerkürede zamanın bu noktasında kusursuzluğu bulduğunu düşünür. Zaman Gezgini’nin eniyileştirilmiş toplumun devamının ancak yeraltında yaşayan Morlock toplumu sayesinde mümkün olduğunu anlaması uzun sürmez:

Işıktan korkan, geceleri yeryüzüne çıkarak Eloileri yiyerek beslenen bu toplum, karanlık ve vahşi göndergeleriyle distopyayı, yeraltında hüküm süren makineleşmiş sanayileriyle de işçi sınıfını esinler. Böylelikle Wells'in kurgusunda düşünen maymun Homo Sapiens'in asırlar sonra sınıf ayrımının sonucu olarak iki farklı türe evrildiği görülür. Bu iki türün toplumsal düzeni eşzamanlı yaşanan ve birbirinin devamını sağlayan bir ütopya-distopya birlikteliği olarak okunabilir.

\section{Zamyatin: Biz}

Birinci Dünya Savaşı'nı takip eden yıllarda, İkinci Dünya Savaşı'na varan süreç boyunca özellikle Avrupa devletlerinin yönetimi yetkeci iktidarların elindedir:

Almanya'da Hitler, İtalya'da Mussolini, Sovyet Rusya'da ise Stalin ülke yönetimlerinde tek adam konumundadır. Buyurgan devlet yönetimi ve baskıcı denetim anlayışının odağında izlenen siyaset yerküreyi yeni bir savaşa doğru sürüklemektedir. Dönemin distopya kurgularında da bu baskıcı, buyurgan iktidarların konulaştırıldığı, güç için her aracı masumlaştıran polis devleti temasını görmek mümkündür. Yevgeniy Zamyatin'in Biz (bkz. Zamyatin, 2012) adlı romanı yetkeci, buyurgan Tek Devlet'in enkötüleştirilmiş toplumsal düzenini konu alır. Eser, London'un Demir Ökçesi'yle birlikte distopya türünün öncü eserleri arasında yer alması ve öncelediği distopyalara esin kaynağı olması bakımından önemlidir. Zamyatin'in 1921 yılında yazımını tamamladığı eserin ülkesi Rusya' da basımına izin verilmemiştir. Roman, ilk kez 1924 yılında İngilizce'ye çevrilerek yayınlanmıştır (Wikipedia, 2016a). Zamyatin'in distopya kurgusu, kusursuzluğun rasyonellikle özdeşleştiği, toplumsal yaşamda rastlantıları ortadan kaldırmayı amaçlayan Tek Devlet adlı enkötüleştirilmiş düzeni konulaştırır. Bu düzen, saf mantığın cennetidir. Bilimsel ilerlemenin büyük ülküsü insanları kusursuzlaştırmaktır ve bu kusursuzlaşma insanın makineleşmesi ile mümkün olacaktır. Böylelikle Zamyatin, Čapek’te işlenen makine-insan karşıtlığını bir adım öteye götürür ve makineye insandan üstün bir değer biçer. 
Tek Devlet düzeninde toplumun üyelerine numaralar adlandırmasıyla seslenilir. Toplumdaki tek basın organı olan Devlet Gazetesi'nde haber ve duyurular "Tek Devlet' in tüm Numaraları (Zamyatin, a.g.e: 11)" ve "Sayın Numaralar! (Zamyatin, a.g.e: 25)” gibi seslenişlerle başlar. İnsanlar, devlet tarafından atanan harf ve sayılarla adlandırılır. Adlandırma, cinsiyete göre düzenlenir: Kadınlar için sesli harfler (örn. O-90, I-330), erkekler içinse sessiz harfler (örn. D-503, R-13) kullanılır. Toplumun üyeleri “Taylorlanmış ritmik mutluluk hücreleri” (Zamyatin, a.g.e: 51) adı verilen duvar yerine şeffaf camların kullanıldığı yapılarda sürekli denetim altında yaşarlar. Her bir saat ne yapacakları Çizelge'ye işlenmiştir ve herkes bu yapılacaklar tablosunu harfiyen takip etmek zorundadır. Enkötüleştirişmiş toplumun resmi düşüngüsü olarak öne çıkan Taylorculuk, Amerikan makine mühendisi ve endüstriyel idare uzmanı olan Frederick Winston Taylor'a yapılan bir göndermedir (bkz. Wikipedia, 2016b). Üretimdeki verimliliğin arttırılmasını amaçlayan bilimsel yönetim kavramının öncüsü olan Taylor, ilk olarak 1911 yılında yayınlanan Bilimsel Yönetimin Prensipleri (bkz. Taylor, 2012) eserinde fabrikalardaki üretimin verimini arttırmak için mühendislik prensiplerini kullanmış ve günümüzde endüstri mühendisliği olarak adlandırılan mühendislik dalının kurucusu olmuştur. Zamyatin, distopyacı bir bakış açısıyla üretimde verim artışı için uygulanan yöntemlerin sonucu olarak gördüğü insanın makineleşmesi temasını enkötüleştirilmiş toplumunun temel taşı olarak seçer. Taylor'un bilimsel yönetim ilkelerinin distopyacı bakış açısından sorgulanan yönü, işçi sınıfının bir üretici araca indirgenmesidir: Taylor'a (a.g.e: 21) göre "maksimum refah ancak bireysel olarak çalışanların günlük mümkün olan en fazla çabayı ortaya koymalarıyla sağlanabilir" ve üretimin kusursuzlaştırılmasının önündeki en büyük engellerden biri işçilerin "kaytarması ve iş yavaşlatması"dır. Aylaklık ve kaytarmayı üretim araçlarına özgü birer kusur olarak konulaştıran Taylor (a.g.e: 23) böylelikle işçi sınıfının insancıl ihtiyaçlarını maksimum refah tanımının dışında bırakarak işçi sınıfını mühendislik bağlamında eniyileştirilmesi gereken makineler olarak gördüğü fikrini esinler.

Bilimi insan yönetiminde bir araç olmaya indirgeyen Tek Devlet, Velinimet olarak nitelenen tekadamın yönetimindedir. Birlik Günü adı verilen, yılda bir düzenlenen seçim günlerinde coşkulu bir tören ile tekadamın yüceltildiği seçeneksiz, açık bir seçim yapılır. Herkes aynı kişiye oy verir. İnsanların tekadamı seçmeme hakkı vardır ancak tekadamın yerine seçebilecekleri başka bir kişi yoktur ve seçimde tekadama red oyu vermek ölüm ile sonuçlanır. Yetkeci devlet, varlığına tehdit olabilecek her hareketi buyurgan, işkenceci yöntemlerle bastırmak için Taylorcu ilkeler bağlamında etkin araçlara sahiptir. Karşıt görüştekiler yandaşlarını ele vermeleri için tekrar tekrar soluksuz bırakıldıkları Gaz Odası'nda işkence görürler. Yönetime boyun eğmeyenlerin sonu insanları sıvılaştıran Velinimet Makinesi’dir.

Zamyatin'in distopyasında toplumsal denetim, adlandırmasıyla Platon'un Devlet'ine gönderme yapan Koruyucular Bürosu tarafindan üstlenilmiştir. Devletin gizli servisi olan bu büro, insanları sürekli olarak gözetim altında tutar ve şüpheli kişileri takip eder. Benzer şekilde cinselliğin yönetimi de bir devlet kurumu olan Seks Bürosu'nun denetimindedir. Distopyacı eleştiride Freud'un öne 
sürdüğü uygarlığın cinselliği baskılayıcı karakterini distopya yazını bağlamında örneklerken de değindiğim üzere insanlar, cinsel ilişkiye girmek için bu büroya başvurur ve cinsel ilişkiye girmek istedikleri kişi için bir pembe bilet edinerek belirlenen randevu saatinde hücrelerinin şeffaf camlarına asılı olan perdeleri indirme hakkı elde eder ve cinsel birliktelikte bulunurlar.

Tek Devlet' in sınırları Yeşil Duvar olarak adlandırılan yüksek, şeffaf duvarlarla çevrilmiştir. Duvara yeşil nitelemesini veren şeffaflığın ardındaki yeşil orman ve okyanustur. Burada sözüm ona düzensiz, uygunsuz bir hayat vardır ve en kötüleştirilmiş toplumun insanları için devletin dışındaki yerküre bilinmezdir. Duvarın en kötüleştirilmiş toplum için önemini, sanatçı olarak işlevi kusursuz toplumu övme görevine indirgenmiş bir şair olan R-13 ile romanın anlatıcı kahramanı, matematikçi D-503'ün aşağıdaki söyleyişinde görmek mümkündür:

R-13'ün ise şaka yapmak gibi bir alışkanlığı vardı.

- Bilgi de neymiş! Bilgi dediğin sizin korkaklığınızdır. Doğru olan nedir ki? Siz sonsuzluğu bir duvarla sınırlandırmaya çalışıyorsunuz, duvarın arkasına bakmaya ise korkuyorsunuz. Evet! Gözleriniz kapalı olarak bakınız. Evet!

- Duvarlar tüm insanlığın temelidir ...- diye başladım. (Zamyatin, a.g.e: 48)

Biz eseri, ütopyadaki bireyselliğin yok edilmesi üzerine yapılan köklü bir eleştiri niteliğindedir. Eserin başlığı, odak noktasına alınan bu eleştirinin altını çizer: Zamyatin'in distopyası Ben'in yerini Biz'e bıraktığı bir dünya kurgusudur. İnsanların sayılara indirgenmesi yalnızca adlandırma ile sınırlı değildir. Hür irade bu toplumsal düzende suçun temel sebebi olarak tanıtlanır ve "bir insanın özgürlüğü 0’a indirgendiğinde(yse) suç işlemez (Zamyatin, a.g.e: 44)" şeklinde yapılan matematiksel gerekçelendirmeyle özgürlük ortadan kaldırılırken yerini karşıtı, toplumsal düzen tarafından yüceltilen özgürlüksüzlük kavramı alır. Hayal kurmayı alışkanlık edinmek, Zamyatin'in enkötüleştirilmiş düzeninde en büyük bulaşıcı hastalıktır ve "ruh illeti” olarak adlandırılır. Tek Devlet, insanın bu kusurlu yönünü ortadan kaldıracak bir yöntem aramaktadır ve bulduğunda da bu büyük buluş insanları makinelerden daha kusursuz yapacaktır. İnsan beyninin hayal kurma işlevine sahip bölümünün keşfi ve bu bölgenin cerrahi bir işlem ile ortadan kaldırılması Tek Devlet'in devamını sağlayan büyük bir gelişme olarak nitelendirilecektir. Somay’ın (a.g.e: 82) yirminci yüzyılın başlarında geri dönüşü olmayan ruhbilimsel rahatsızlıkların belirtilerini bireyin kişiliğini ve zekasını yitirmesi pahasına ortadan kaldıran bir cerrahi işlem olan lobotomiye gönderme yaparak "fantasiektomi" olarak adlandırdığı bu işlem, Zamyatin'in Taylorcu bilimsel verimlilik anlayışının insanı makineye indirgemesiyle sonuçlanacağı yönündeki eleştirisinin doruk noktasıdır.

Romanın anlatıcı-kahramanı D-503, Entegral adlı bir uzay gemisinin yapımının baş sorumlusudur. Enkötüleştirilmiş toplum düzenine koşulsuz boyun eğişi, kurduğu hayallerle sarsılmaya başlar. Kahramanın başına gelen bu durum, saf mantıkçı kusursuz düzen içinde hayatını sürdüren bir matematikçi için anlamlandırılamazdır. Tanımlayamadığı bu hayal görme alışkanlığını adlandırmak için toplumsal düzenin mantıkçılığını temsil eden ve kahramanın uzmanlık alanı olan matematikten bir terim seçer: Hayal görmek, gerçekdışı, kaotik, ürkütücü 
bir deneyimdir ve kahraman tarafindan bir sanal sayı olan i'nin değeri $\sqrt{ }-1$ ile adlandırılır. Bireyin enkötüleştirilmiş düzendeki gerçek-hayal düzlemine indirgenen kişilik çatışması da böylelikle sayısal bir çerçeveyle sınırlandırılmış olur.

Kahramanın ütopya sandığı düzenin aslında bir distopya olduğunun farkına varışını betimleyen uyandırıcı yolculuk London'un Demir Ökçe eserindekine koşut olarak karşıcins bir karakterin romanın kahramanıyla ilişkiye geçmesiyle ivmelenir. I-330 adlı bu karakter, Yeşil Duvar'ın ardındaki düzene karşıt, devrimci grubun bir üyesidir ve D-503 ile ilk tanışması bir cinsel ilişki aracılığıyla olur. Uzay gemisi Entegral'i ele geçirmek için D-503'ten yardım alan I-330 ve arkadaşlarının yaptığı başarısız devrim denemesi sonucu enkötüleştirilmiş toplumsal düzen I-330'u işkence ve ardından ölüm ile cezalandıracak, D-503'ün de hayallerini elinden alarak böylelikle ona yeniden boyun eğdirecektir.

Zamyatin'in Biz eseri, London ile başlayan çağdaş distopya türünün kişiliğini belirleyici bir rol üstlenir. Ardından gelen birçok eser, distopya türü içerisinde yer edinirken Zamyatin'in eserine olan benzerlikleri siralanarak betimlenecektir. Zamyatin'in distopyasını kurgularken temel aldığı yöntemler, çalışmamın bütüncesini oluşturan Orwell'in 1984 eseri için de önemli bir esin kaynağıdır ve distopya yazınının özelliklerini incelediğim bölümde irdelenecektir.

\section{Huxley: Cesur Yeni Dünya}

Aldous Huxley tarafindan yazılan ve ilk olarak 1932 yılında yayınlanan Cesur Yeni Dünya romanı (bkz. Huxley, 2011), distopya yazın türünün bir diğer önemli eseridir. Roman, bir denetim aracı olarak baskı ve işkenceyi ilkel bir yöntem olarak gören, gelişkin denetim yöntemlerine sahip enkötüleştirilmiş bir toplumsal düzen olan Dünya Devleti'ni konu alır. Londra' da 2540 yılında geçen kurgu, aradan geçen yüzyıllardan sonra insan toplumunun yönetimi bağlamında enkötüleşen toplumsal düzenin kusursuzlaşmasında bilimin etkin rolünü bir adım öteye taşır. Zamyatin'in distopyasında denetimi sağlayan, cezalandırıcı ve caydırıcı işlevleri öne çıkan yöntemlerin yerini Huxley'nin distopyasında iktidarın emrine sunulan, karşıt direnişi henüz ortaya çıkmadan önleyici ve engelleyici işlevlere sahip yöntemler alır. Dünya Devleti'nde enkötüleştirilmiş toplumsal düzenin temelini insanların zeka seviyelerine göre sınıflandırıldığı bir tür kast sistemi oluşturur. Cinselliğin baskılandığı ve denetlendiği distopyaların aksine Huxley'in distopyasında insanın üremesi bütünüyle devletin elindedir: "Kuluçka ve Şartlandırma Merkezi” olarak adlandırılan devlet kurumu, seri insan üretimiyle uğraşır. "Bokanovskileştirme" adı verilen işlemlerle insan embriyosu yapay bir ortamda döllenir ve doğumdan önce bireylerin zeka seviyeleri belirlenir: Seviyelere göre beş kasta ayrılan toplumunda sınıflar Yunan alfabesinin harflerine göre, hiyerarşik biçimde Alfa, Beta, Gamma, Delta ve Epsilon olarak adlandırılır. İnsan üretimi teknolojisine koşut olarak gelişmiş olan uykuda öğretim, ruhbilimsel manipülasyon ve klasik koşullama gibi yöntemlerle toplumun bireyleri, üyesi oldukları sınıfların içinde kendilerini ömür boyu huzurlu hissederler. Huxley’nin distopya düzeninde yönetim böylelikle her tür olası sınıflararası çatışmayı engellemiş olur. 
Bezel'e (1984b: 98) göre Huxley’nin distopyasındaki toplum düzenini diğer ütopya ve distopyalardan ayıran temel nitelik, insan doğası ve toplum düzeni arasındaki etkileşimin diğer örneklerdeki karşılıklı yapısının aksine Cesur Yeni Dünya'da tek yönlü oluşudur. Böylelikle insan doğası da toplumsal düzenin enkötüleştirilmesinde bir araç olur. Bezel, bu etkileşimi şöyle betimler:

Kurulu bir düzen vardır. Bu düzenin sürmesi için gerekli insanlar önceden saptanan nitelik ve ölçülere göre ve istenen sayıda, fabrikalarda üretilir, koşullandırma merkezlerinde büyütülür. Ismarlama insan yaratma konusunda bilim ve teknolojideki uygulamaların başarısı mutlaktır. Üretim kusurları hesaba katılmayacak kadar küçüktür (Bezel,1984b: 98).

Huxley’nin distopyasının engelleyici yöntemleri bireylerin enkötüleştirilmiş topluma karşı tertiplemeleri olası her tür eylemi önleyici niteliktedir. İnsanın seri üretimi sayesinde cinsellik insan üremesinden bütünüyle soyutlanmıştır. Artık cinselliğin baskılanmasına gerek yoktur çünkü cinsellik yaşamın devamı için bir ihtiyaç değildir. Enkötüleştirilmiş toplum düzeni, cinselliği üremeden ayırışıyla birlikte bu olguyu pornografik olarak niteleyerek çirkinleştirir; anne, baba ve aile kavramlarını da bu pornografik çirkinlik çerçevesine dahil ederek toplumsal düzenin dışında bırakır.

Cesur Yeni Dünya kurgusunda direnişi engelleyici diğer bir önemli yöntem de insanlara sonsuz mutluluk kaynağı olarak devlet tarafından sunulan soma adlı uyuşturucudur. Kitabın 1946 yılı baskısında ilk olarak metne eklediği önsözünde Cesur Yeni Dünya'da dönemin toplumuna yönelttiği eleştirileri savunan Huxley (a.g.e: 15), enkötüleştirilmiş toplumun temeli olarak gördüğü "kölelik sevgisinin" ancak "insan zihin ve bedenlerinde derin ve kişisel bir devrim sonucu başarılabileceğinin” altını çizer. Yazar, bu devrimin gerçekleşmesi için gerektiğini savladığı üç buluşu şöyle sıralar:

Birincisi, çocuk şartlandırma ve daha sonra skopolamin gibi ilaçlar yardımıyla sağlanacak ileri bir telkin tekniği. İkincisi, devlet idarelerince, eldeki herhangi bir bireyi sosyal ve ekonomik hiyerarşide ait olduğu yere atayabilme olanağı sağlayacak, insan farklılıkları üzerine tam gelişmiş bir bilim dalı. ...Üçüncüsü (...), alkol ve diğer uyuşturucuların yerini alacak, daha az zararlı, ama aynı zamanda cin ya da eroinden daha fazla keyif verecek bir madde (Huxley, a.g.e: 16). Soma kullanımıyla toplumun bireyleri her tür şüpheci, sorgulayıcı düşünceden arındırılır ve huzur için enkötüleştirilmiş düzene bağımlı duruma getirilir. Romanda Dünya Devleti’yle özdeşleşen “Cemaat, Özdeşlik, İstikrar” savsözü düzenin bireyi ögütücü, sindirici işlevini özetler niteliktedir. Bütünüyle yönetime bağımlı olan toplumun üyeleri, distopyacı bakış açısıyla koşullandırılmış maymunlar olarak, iğneleyici bir göndergeyle, kusursuz makinelerden üstün bir seviyeye çıkartılmış olur.

Huxley'nin distopyasında olay örgüsü ve karakterlerin toplumdaki konumları Zamyatin'in Biz’ine koşut niteliktedir. Yerkürede Dünya Devleti'nin dışında kalan bir bölge vardır ve tıpk1 Zamyatin'deki gibi bu bölge de vahşi doğa olarak tanımlanır. Enkötüleştirilmiş toplumsal düzenin betimlenmesinin ardından olay örgüsü, hikayenin baş karakteri Beta sınıfı üyesi, kadın işçi Lenina Crowne’un Alfa sınıfı üyesi erkek psikolog Bernard Marx ile Dünya Devleti 
topraklarının dışında kalan bu vahşi bölgeye yaptıkları ziyaret ile başlar. Lenina ve Bernard burada geçmişte Dünya Devleti vatandaşı olan ancak hamile kaldıktan sonra utancından vatanına geri dönemeyen Linda ile tanışırlar. Enkötüleştirilmiş düzen ile çatışma, Linda ve oğlu vahşi John'un hikayenin baş karakterleri tarafından Dünya Devleti'ne getirilmesiyle başlar. John okumayı annesinden öğrenmiştir ve çocukluğunda sıklıkla Shakespeare'nin eserlerinin derlendiği bir kitabı okumuştur. John'un hayallerinde Dünya Devleti, Huxley'nin Shakespeare'nin Fırtına oyununa gönderme yaparak adlandırdığı "Cesur Yeni Dünya”dır. Annesiyle birlikte Dünya Devleti'ne yerleşen John vahşi olarak nitelendirilecek ve toplumun üyelerine teşhir edilerek alışkanlıkları ve davranışları alay konusu edilecektir. John'un enkötüleştirişmiş düzenin ortasında insanlardan ayrık bir yaşam kurma çabası başarısız olacak ve uyumsuzluk, karakterin intihara sürüklenmesiyle sonuçlanacaktır. Annesi Linda ise düzenli olarak yüksek dozlarda soma kullanarak kendini uyutarak yavaş, acısız, huzurlu bir ölümü seçecektir. Böylelikle enkötüleştirilmiş düzen, kendine özgü yöntemleriyle iki karakteri de sindirerek yok olmaya sürükleyecektir. Huxley'nin distopya kurgusu, kişi ve kurum adlandırmalarının gerçek dünyaya yaptığg göndermelerle öne çıktığı bir eserdir. Distopya yazını çevirisi bağlamında da önemli olan bu adlandırmalarda dönemin önde gelen düşünürlerine yapılan göndermeler ön plandadır. Dünya Devleti’nin ütopyada yazınında incelediğimiz yüce kral kişileştirmesine gönderme yapan kurucusu Henry Ford'dur. Soyadıyla aynı adı taşıyan Amerikan araba firmasının kurucusuna yapılan bu gönderme, Huxley'nin Amerika gezisi sonrası distopyasını yazmaya karar verişi göz önünde bulundurulduğunda dikkat çekici olur. Dünya Devleti’nde Ford, bir kelime oyunuyla İngilizce'de tanrıyı nitelemek için çokça kullanılan Lord sözcüğünün yerini alır: Tanrıya "Fordumuz" diye seslenilir, y1llar "Ford'dan önce", "Ford' dan sonra" nitelemeleriyle açımlanır. Ford firmasının Huxley’nin kitabı yazdığı dönemde seri üretimine başladığı Model T arabasının adındaki T harfi sembolleştirilerek Dünya Devleti’nde Hıristiyanlığın simgesi olan haç sembolünün yerini almıştır. Cesur Yeni Dünya eserinde yüce kral imgesinin düzeni enkötüleştiren insan imgesine evrimine koşut olarak romanda kullanılan karakter adlarının tümü gerçek dünyada dönemin tanınmış kişilerine göndermeler olarak okunabilir. Örneklendirmek gerekirse, Bernard Marx adlandırması İrlandalı yazar-eleştirmen George Bernard Shaw ile filozof-iktisatçı Karl Marx’a, Lenina Crowne adlandırmasıysa Ekim Devrimi'nin öncüsü Vladimir Ilyich Ulyanov'a, sık kullanılan mahlasıyla Lenin'e yapılan göndermeler olarak okunabilir. Distopya yazınında adlandırmalar aracılığıyla yapılan bu göndermeler bütüncemi oluşturan 1984 eserinde enkötüleştirilmiş düzenin bir adım öteye girerek yeni bir dil tasarlamaya girişmesiyle farklı bir düzleme taşınacak, böylelikle özgün adlandırmalar ile türenti kelimelerin çözümlenmesi ve çevirisi yazın çevirisi bağlamında değerli bir inceleme malzemesi olacaktır.

\section{Distopya Yazınının Özellikleri}

Biz ve Cesur Yeni Dünya romanları, 1984 romanıyla birlikte distopya yazın türünün önde gelen üç eseri olarak nitelendirilir. Yazın türüne özgün biçim ve biçem ile birlikte olay 
örgüsü ve distopya kurgularındaki koşutluklar bu üç eseri metinlerarası ilişkileriyle incelemeyi gerekli kılar. Bu üç eser ile çerçevesi çizilen distopya yazın türünün özelliklerini türe ait diğer eserlerin metinlerarası koşutluk ve karşıtlıklarını inceleyerek bütüncül bir bakış açısına ulaşmak mümkündür.

Distopya yazın türü kapsamına dahil edilen eserlerde dikkat çekici birçok benzerlik saptanabilir. Bu benzerliklerin yazın türüne özgün olan yönlerini çözümlemek için uygun bir yöntem, benzerliklerin distopya eserlerinde kurgulanan enkötüleştirilmiş toplumsal düzen içindeki işlevlerini saptamaktır. Biçimsel ve biçemsel koşut özelliklerin çözümlenmesi böylelikle distopya yazını çevirisinde çevirmenin karşılaştığı sorunlara 1şık tutacak nitelikleriyle sıralanabilir.

\section{Olabilirlik: Ütopya Karşıtı Eleştiri}

Distopya yazını eserlerine özgün olan eleştiri iki sınıfa ayrılabilir. Ütopya karşıtı eleştiri olarak adlandıracağım ilk sınıf, belli bir ütopyacı düşüngü ve bu düşüngünün belirlediği yöntemlerle tasarlanan eniyileştirişmiş düzene içkin olası yetersizliklerin ve tutarsızlıkların saptanmasıdır.

Distopya kurguları, hikayelerin sıfır zamanında birer ütopya olarak resmedilir. Yazar, ütopya yazını eserleriyle ve/ya da ütopyacı bir düşüngüyle metinlerarası ilişkiler kurar ve böylece distopyasını bir ütopya ile özdeşleştirir. Sıfır noktasında ütopya ile özdeşleşen kurgu artık çıktığ1 yol boyunca en iyinin en kötüye dönüşümünün izini sürecektir. Distopya böylelikle olabilirliğini gerekçelendirmiş olur.

Metinlerarasılık, ütopya karşıtı eleştirinin temelindedir. Örneklendirmek için distopya yazınında ütopya yazını eserlerindekine koşut olarak kullanılan söyleyiş biçimini gösterebiliriz. Söyleyiş, sorgulama ve ütopyanın olabilirliğini gerekçelendirme sürecidir. Ütopyayı bilen özne ile ütopyayı merak eden özne arasında geçer. More'un anlatıcısı Hythloday’in örnek yazar ile söyleşisi de bu bağlamda geçerlidir. Aynı biçimi Campanella'nın, Bacon'un ütopyalarıyla London'un, Zamyatin'in ve Huxley'nin distopyalarında da görmek mümkündür.

Söyleyiş biçiminin koşutluğu ütopyacı ve distopyacı öznelerin rollerindeki farklılığın altını çizer: Distopyada söyleyiş, kurgulanan toplumsal düzeni ütopya sanan özne ile düzenin distopya olduğunu bilen özne arasındadır. Distopya kurgularının olabilirliklerini gerekçelendirmek amacıyla kendilerini ütopyalarla özdeşleştirmek için kullandıkları bir yöntem de adlandırmalardır. Distopyalar, ütopyalarda aynı ya da benzer adları taşıyan kişi veya kurumlara karşıt işlevler yükleyerek kendilerini önceleyen ütopyaların kusursuzluğunu sorgular. Örneğin, Platon'un Devlet'inde halkın güvenliğinden sorumlu Koruyucular sınıfının Zamyatin'in Biz’inde Koruyucular Bürosu adıyla polis devletin fişleyici gizli servisine evrildiğini görürüz. Bacon'un ütopyasındaki alışılageldik isimler yerine işlevleriyle adlandırılan "Güç”, "Sevgi” gibi yöneticilerin Orwell'in 1984'ünde Sevgi Bakanlığı, Barış Bakanlığı gibi kurum adlarına esin kaynağı olduğuna değinmiştim: Sevgi Bakanlığı, düzeni korumak için baskı ve işkence konusunda uzmanlaşırken Barış Bakanlığı'nın görevi, hiç bitmeyen savaşlarla ilgilenmektir. 
Adlandırmalardaki metinlerarası ilişkiyi toplumsal düzendeki rolleriyle tanımlanan ütopya yazını karakterlerinin distopya kurgusunda enkötüleşen imgelerinde de görmek mümkündür. Yüce kral imgesinin bu bağlamda ütopyadan distopyaya gelindiğinde isimsizleşerek bir kat daha yüceltildiği ve her şeyi bilen niteliğinin yerini her şeyi gören niteliğine bıraktığı görülür. Böylelikle insansı kusurlarından arınan tekadam, ulaşılmaz, görünmez nitelikleriyle kâbusun yaratıcısı olur: Her şeyin doğrusunu bilen ve uygulayan insan olarak yüceltilen More'un Kral Utopus'u Bacon'da adındaki dini göndergelerle tanrılaşan Kral Solamona'ya evrilir. Zamyatin'in Biz'inde yücelen tekadam seçeneksiz seçimlerin tek galibidir ve adının yerini niteliği Velinimet almıştır. Bütüncemi oluşturan 1984 eserinde de, daha sonra detaylandıracağım üzere, tekadam imgesi artık büsbütün görünmez, ulaşılmaz olan Büyük Birader karakterinde belirecektir. Böylelikle distopya, tekadamın kusursuzluğundaki dogmatik yönü kıyasıya eleştirir.

\section{Gerekçelendirme: Geriye Dönük Eleştiri}

Her ne kadar distopyalar, ütopyalara karşıt bir tutum sergilese de distopya yazını bir yazın türü olarak ütopya türüyle kurduğu metinlerarası ilişkilerle evrilmiş ve yirminci yüzyılda kendi çerçevesini belirleyerek özgün bir yazın türü haline gelmiştir. Söylem düzleminde ütopyaya karşıtlığıyla kendini tanımlayan ve gerekçelendiren distopya, ütopyaların gerçek topluma yönelttiği eleştirileri de kendisine miras olarak almıştır. Gerçekten kurguya doğru çıkılan yolculuğun adımları sırasıyla gerçek, ütopya ve distopya olarak belirlenir. Böylelikle distopya, geriye dönük eleştirisini dönemin gerçek toplumuna yöneltirken kendisini önceleyen ütopyayı hazırlayan nitelikleri konulaştırır. Zamyatin, Tek Devlet düzeninin temeline, yazıldığı döneme yönelik bir eleştiri olarak okunabilecek Taylorculuk düşüngüsünü yerleştirir. Bilimsel verimlilik anlayışı, insanların makineleşmesine ve enkötüleşen toplumsal düzenin yücelmesi için bireyselliğin yittiği bir tektipleşmeye yol açar. Hayaller bireyselliğin en büyük savunusudur ve alaysılı bir biçimde hayallerin yok edilmesi Tek Devlet'in büyük hayali olarak sunulur.

Distopya türünün bir diğer örneği olan Katharine Burdekin'in ilk olarak 1937 yılında yayınlanan Swastika Geceleri (bkz. Burdekin, 2015) adlı eseri İkinci Dünya Savaşı’nı önceleyen dönemde Hitler yönetimindeki faşist NSDAP partisinin Almanya'da yükselişine bir tepki olarak kaleme alınmıştır. Yazar, distopyasında Hitler'in Bin Yıllık Alman İmparatorluğu nitelemesinden esinlenerek döneminden yedi yüz yıl sonra dünya yönetimini elinde bulunduran Hitler yönetimini anlatır. Aradan geçen yüzyıllar sonrasında Hitler, insansılığından bütünüyle sıyrılıp tanrısal bir imgeye dönüşmüştür. Enkötüleştirilmiş toplumsal düzenin üyeleri ona "Efendi Hitler" (örneğin, bkz. Burdekin, 2015: 25) olarak hitap eder ve insanlar hayatlarını dinsel bir kitap olan "Hitler İncili”ndeki buyruklara göre yaşar.

Huxley’nin Dünya Devleti, yazarın Amerika Birleşik Devletleri’ne yaptığı ziyaret sonrası gözlemlediği tüketim toplumuna dair duyduğu korkuların kurgu dünyaya taşınmış şeklidir. Benzer şekilde Ray Bradbury'nin ilk olarak 1953 yılında yayınlanan distopyası Fahrenheit 451 (bkz. Bradbury, 2012) de gelecekteki Amerikan toplumunun enkötüleştirilmiş düzenini konu 
alır: İtfaiyecilerin görevi kitapları yakmaktır ve küçük bir grup insan kitapları ezberleyerek nesilden nesile taşımaya gayret etmektedir. Bütüncemi oluşturan Orwell'in 1984 eserinde enkötüleştirilmiş düzen Parti'nin denetimindedir. Parti üyeleri kendisini önceleyen gerçek dünyadaki yetkeci rejimlere geriye dönük göndermeler yaparak alaysılı bir biçemle bu baskıcı yönetimlerden büyük dersler aldıklarını belirtirler. Hikayenin kahramanı Winston'un Sevgi Bakanlığı'nda işkence görürken sorgucusu, Parti üyesi O'Brien'ın yaptığı geriye dönük göndermeler uygun bir örnek niteliğindedir. O’Brien, aşağıdaki alıntıda Orta Çağ' dan metnin yazıldığı döneme kadar Parti’nin örnek aldığı baskıcı yönetimleri sıralar ve enkötüleştirilmiş düzenin bu örneklerden nasıl beslendiğini anlatarak geriye dönük eleştirisini alaysılı bir biçem kullanarak yapar: “Anlaman gereken ilk şey, burada şehit diye bir olay olmadığıdır. Geçmişteki dinsel kıyımları okumuşsundur. Ortaçağlarda Engizisyon vardı, ama başarılı olamadı. Doğru yoldan ayrılanları yok etmek amacıyla işe başladı. Ama sonunda yok olan kendisi oldu. Çünkü kazığa bağlayıp yaktığı her adamın yerine binlercesi çıktı. Neden böyle oldu? Çünkü Engizisyon, düşmanlarını herkesin önünde tövbe etmeden öldürüyordu. Öldürme nedeni zaten suçluların tövbe etmemeleriydi. İnsanlar gerçek inançlarından vazgeçemedikleri için ölüyorlardı. Aslında tüm onur suçlunun, tüm utanç ise onu yakan Engizisyonun oluyordu. Daha sonraları, yirminci yüzyılda totaliterler vardı. Alman Nazileri ve Rus Komünistleri. Ruslar doğru yoldan ayrılanları, Engizisyondan daha şiddetli cezalandırdılar. Geçmişteki yanlışlardan öğrenmişlerdi; şehitler yaratılmamalıydı. Kurbanlarını mahkeme önüne çıkarmadan önce insanlık onurlarını öldürüyor, aç bırakarak, işkence ederek, tüm dirençlerini kırıyorlardı. Sonuçta kendilerine ne söylenirse kabul ediyorlar, birbirlerini ele veriyor, birbirlerinin ardına gizleniyorlar, acıma dileniyorlardı. Âmâ birkaç yıl sonra aynı şeyler yinelendi. Ölenler şehit oldular; alçaldıkları unutulmuştu. Neden böyle olmuştu? Çünkü, itiraflarının düzmece olduğu ve işkence yoluyla elde edildiği anlaşılmıştı. Biz bu tür yanlışlar yapmıyoruz. Buradaki tüm itiraflar doğrudur. Onları biz doğru yapıyoruz. En önemlisi, ölülerin bize karşı çıkmak için dirilmelerini önlüyoruz. Sonraki kuşakların seni savunacağını sakın düşünme, Winston. Sonrakiler senin adını bilmeyecek, seni tarih zincirinden söküp atacağız. Seni gaz haline sokup atmosfere salacağız. Senden geriye hiçbir şey kalmayacak; ne bir ad, ne bir kayıt, ne de beyinlerde bir anı. Geçmişten olduğu gibi, gelecekten de silineceksin. Sen hiç yaşamamış olacaksın." (Orwell, 2008: 222) Orwell'in distopyası böylelikle kendini tekil bir ütopyacı düşüngünün sonucu ortaya çıkan bir kâbus olarak tanımlamak yerine dönemindeki ve geçmişteki yetkeci yönetimlerin kötü özelliklerinin harmanlandığı bir tablo olarak karşımıza çıkar.

\section{Soyutlama: Bilim-Kurgu İlişkisi}

Ütopya yazınının tarihsel evrimine baktığımızda özellikle klasik ütopya eserlerinde öne çıkan ada kavramıyla karşılaşırız. Ütopya yazarı, kurgu düzenini gerçek düzenden soyutlayarak gerçek toplum düzenine karşı bir tür yabancılaşma sağlar. Böylelikle düzeninin aksayan yönlerini ve eniyileşme yolunda yapılması gerekenleri önyargısız, dışarıdan bakan bir gözle 
betimleyebilir. Distopya yazını, ütopyaların aksine, soyutlamayı gerçekten yabancılaşmak için değil kendini gerçek ile gerekçelendirmek için kullanır. Dolayısıyla distopyalarda soyutlamanın uzam düzleminden ziyade zaman düzleminde çokça belirdiğini görürüz. Distopya kurguları uzam olarak kurgu bir adayı seçmek yerine okurun bildiği, tanıdığı gerçek dünyaya konuşlanır ve zamanı ileriye alır. Eserlerin yazıldığı zamanda gerçek dünyada enkötüleşmekte olanın gelecekte enkötüleşmiş olan hâlini okura yansıtarak herhangi bir önlem alınmazsa gelinebilecek noktayı betimler. Böylelikle okuru eyleme teşvik edici, uyarıcı bir işlev edinir. Hikayelerinin sıfır zamanı yüzyıllar ötesinde olan distopyalar, ütopyalarda yönetimin sürdürülmesi için bir araç olarak kullanılan bilime koşut olarak, enkötüleşen düzenin bireysellikle savaşında gelişmiş teknolojik araçlar kullanır. Geriye dönük eleştirinin önemli bir unsuru olan bu bilim-kurgu ilişkisi distopyaların uyarıcı işlevlerini arttırmasına yardım eder. Zamyatin'de insanların hayal etme gücünü elinden alan fantasiektomi işlemini, Huxley'de enkötüleştirilmiş düzenin sürdürülmesi bağlamında alkol ve eroinden daha kullanışlı olan soma adlı uyuşturucuyu ve düzenin devamı için cinselliğe olan gereksinimi büsbütün ortadan kaldıran bokanovskileştirme işlemini bu çerçevede ele alabiliriz. Orwell'in 1984'ünde de yönetim, insanları her an, her yerde teleekran adı verilen aletlerle izlemektedir. Gelişkin birer televizyon olarak nitelendirilebilecek bu aletler sağladıkları çift yönlü veri aktarımıyla denetimin önemli bir öğesi olur: İnsanlar teleekranı seyrederken, Parti de insanları seyretmekte ve insanlara emirler vermektedir.

\section{Sürdürülebilirlik: Baskı, Denetim Tasarıları}

Distopyalarda devlet düzenleri iktidarlarını sürdürebilmek için çeşitli denetim yöntemlerine başvurur. Biçimsel yapıları her kurguda farklılık gösterse de bu denetim yöntemlerinin ortak özelliği bireyin üyesi olduğu toplumsal düzenin büsbütün eniyileşmiş bir düzen olduğunu kanıksamasını sağlamalarıdır. Sorgulama ve eleştirinin yokluğunun konulaştırılması distopya düzenlerinin dogmatik niteliklerini vurgular. Yazar, böylelikle örnek okuru kendi düzenini eleştirmeye ve sorgulamaya teşvik eder. Zamyatin ve London ile başlayan distopya geleneğinde denetimi sağlayan öncelikli yöntem baskı ve sansür olagelmiştir. Demir Ökçe'de kentsoylu sınıf, baskı için emrindeki yargı, basın ve kiliseyi kullanır. Zamyatin'in Tek Devlet'inde Koruyucular Sınıfı cam evlerde oturan insanları sürekli olarak gözler ve izler. Baskıcı denetimin şiddet içeriğinin London'dan Zamyatin'e ve ardından Huxley’e gelindiğinde azaldığı görülür: Zamyatin'de insanlar enkötüleştirilmiş düzene koşulsuz boyun eğişlerini yadırgamaz veya sorgulamazlar. Hür irade insanlar için suç ile eşdeğerdir. Özgürlügüü yerini özgürlüksüzlük almıştır. Baskıyı sağlayan en büyük araç olan Velinimet Makinesi’nin caydırıcı niteliği, adını Tek Devlet' in yöneticisi Velinimet'den alışıyla kutsallaştırılır. Huxley’nin Cesur Yeni Dünya'sında bilim, denetimin şiddetsizleştirilerek kolaylaştırılması bağlamında doruk noktasına çıkar: İnsanlar henüz doğmadan zihin seviyeleri belirlenir. Uykuda öğrenim ile toplumun üyeleri devlete sorgusuz boyun eğmeleri için koşullandırılırlar. Devlet, sonsuz mutluluğu, uyuşturucu biçiminde kolay elde edilebilir ve tüketilebilir bir biçimde insanlarına sunar. George Orwell'in 
1984'ünde Huxley'deki denetimin şiddetsizleşmesine karşılt olarak baskı yöntemlerinin enkötüleştirilmesi konulaştırılır. İnsanlar sürekli olarak izlenir ve düzene karşıt bir eylemde bulunduğuna dair şüphe uyandıran her kişi buharlaştırılır: Sevgi Bakanlığı'na gönderilen bu suçlular, yoğun bir işkence sürecinden geçerek benliksizleştirilirler. Devlet, kişilerin ismini ve bu kişilerle ilgili her detayı geçmiş yayınlardan kaldırır ve tarihi yeniden yazar.

\section{Çevirilere Kuramsal Çerçevede Yaklaşım}

Çevirmenin Biçemi: Kavramın Gelişimi ve Artalanı Çeviribilim, kendi çerçevesini çizerek dilbilimden ayrılan bir disiplindir. Bu açıdan bakıldığında çeviribilim, dilbilimden birçok yaklaşım ve yöntemi miras olarak almıştır. Kaynak odaklı çeviri yaklaşımlarını bu mirasa örnek gösterebiliriz. Kaynak odaklı yaklaşımların yerini erek odaklı yaklaşımlara bırakışı çeviribilimin dilbilimden koparak evrilmesini betimler niteliktedir. Çevirmenin biçemi kavramının izini kaynak dilden erek dile doğru kayan bu odaklanışa koşut olarak sürmek mümkündür.

Çeviride Kayma Kavramı: Catford, Popovič Çeviriyi açıklayan dilbilimsel yaklaşımlar, dilbilimin doğası gereği dil düzleminden yola çıkar ve çoğu kez kendini bu düzlem ile belirlenen çerçeveye sınırlar. İlk kez dilbilimci J.C. Catford tarafından ortaya atılan kayma kavramı, çeviri olgusuna dil düzleminde, biçimsel bir bakış açısıyla yapılan bir açıklama niteliğindedir. Catford, kayma kavramını yine ilk kez kendisi tarafından tanımlanan biçimsel denklik kavramına gönderme yaparak tanımlar: Biçimsel denklik, "her türlü erek dil kategorisinin (birimi, sınıfı, yapı vb.) erek dilin ekonomisi içinde, aynı belli bir kaynak dil kategorisinin kaynak dilde kapladığı gibi, mümkün olduğunca aynı yeri kaplamasıdır (Berk, 2005: 98).” Bu kavramdan hareketle Catford'a göre kayma "kaynak dilden erek dile giden süreçte biçimsel denklikten sapma olarak tanımlanır (Berk, a.e: 131)." Catford'da kayma kavramı, biçimsel yapının bir öğesi olarak dil düzleminde sınırlı kalır. Dilbilimci, bu düzlemde dil-çiftleri arasında olası kaymaları sınıflara ayırarak çözümler. Örneğin, Türkçe'de tekil gözlük kelimesinin İngilizce karşılığının çoğul glasses kelimesi oluşu, Catford'un sistemiçi kayma (ing: intra-system shift) olarak adlandırdığı kayma sınıfına girer. Dil düzleminde sınırlı kalan kayma kavramı, çeviri olgusunun yalnızca bir bölümünü açıklayabilir niteliktedir. Slovak çeviribilimci Popovič, kayma kavramının anlam alanını genişleterek bu kavramı biçemsel eşdeğerlik çerçevesinde deyiş kaymaları adıyla çözümler. Çeviride eşdeğerliği aşamalı bir sıralamayla dilsel, dizisel, biçemsel ve metinsel olarak dört sınıfa ayıran Popovič, çeviride - özellikle yazın çevirisinde - biçemsel eşdeğerliğin önemini vurgular (Yazıcı, 2010: 83). Deyiş kaymalarının "yapıtın özgün bütünlüğünü korumak amacı taşıdığını (Yazıcı, a.e: 84)" ifade eden Popovič, kaymaları yapısal, türsel, bireysel, olumsuz ve konusal kaymalar olarak beş sınıfa ayırır. Catford'da dil düzleminde sınırlanan kayma kavramı Popovič’e gelindiğinde metin düzlemini ve çevirmen seçimlerini içine alacak şekilde genişletilmiş olur. Catford'un dil düzleminde incelediği kaymaları yapısal kaymalar sınıfına yerleştiren Popovič, türsel kaymalarla metin türündeki, bireysel kaymalarla da çevirmen seçimindeki farklılıkları konulaştırır. 
Çeviri Düzenlilikleri: Toury Çeviribilimde betimleyici yaklaşımın öncüsü kabul edilen İsrailli çeviribilimci Gideon Toury, çeviri araştırmalarını "çevirilerin erek ekin ürünü olduğu önseli ile, çevirilerin aynen kaynak ekindeki özgün yapıtlar gibi erek ekinde de bir konumu ve işlevi olduğu düşüncesinden (Yazıcı, a.e.: 130)" hareketle Erek Odaklı Kuram'ını geliştirmiştir. Toury'nin erek odaklı kuramı, Even Zohar'ın Çoğul Dizge Kuramı'ndan yola çıkar ve çevirilerin erek ekindeki konumunu ve işlevini bulgulamayı amaçlar. Toury'nin bütünce çözümlemelerinin önünü açan erek odaklı betimleyici yaklaşımı, bir ekinde egemen olan çeviri davranışlarını çözümlemek için çeviri normlarını belirler. Çeviri olgusunu "normların yönlendirdiği bir eylem (Yazıcı, a.e: 134)" olarak açıklayan Toury, çevirmenin bireysel kararlarını, erek ekine egemen olan çeviri politikasını ve çevirmen seçimlerini sırasıyla önsel, süreç öncesi ve çeviri süreci normları olarak adlandırdığı normlar çerçevesinde inceler. Böylelikle ekine özgü çeviri yaklaşımları (örn. kaynak ya da erek odaklı yaklaşım) ve düzenlilikleri (örn. açıklama, basitleştirme, normalleştirme vb.) belirlenebilir.

Çevirmenin Biçemi: Yazın Çevirisi İlişkisi Çevirilerin erek ekin ürünleri olarak tanımlanması, kaynak odaklı yaklaşımlarda kaynak metne biçilen üstün değerden ötürü görmezden gelinen çeviriyle ilgili birçok olgunun açıklanmasına olanak sağlar. Bu yaklaşımın etkilerini yazınsal içeriğinden ötürü kaynak metnin rolünün bir kat daha baskınlaştığı ve çeviri olgusunun sıklıkla görmezden gelindiği yazın eleştirisi ve çevirisi alanlarında da görmek mümkündür.

Çevirmenin Sesi: Yönlendirmeciler Okulu “Belçika ve Hollanda'da, 1970’li yıllarda çeviri araştırmasını, karşılaştırmalı yazınbilimin bir parçası olarak sürdüren çeviri kuramsal bir ekol (Stolze, 2013: 168)" olan Yönlendirmeciler Okulu (ing. Manipulation School), yazın çevirisi olgusunu aralarında koşut betimleyici bir yaklaşımla irdeleyen, André Lefevere ve Theo Hermans gibi dönemin önde gelen çeviribilimcilerini kapsayan birçok araştırmacıdan oluşur. Araştırmacıların yaklaşımlarının temelinde çeviri olgusunun yazınsal incelemeler bağlamında yadsınamayacak bir yeri olduğu görüşü yatar. Bu görüş, Toury’nin çeviriyi erek dizgenin bir öğesi konumuna yükselttiği erek odaklı kuramıyla gerekçelendirilir. Hermans, okula adını veren yönlendirme olgusunu şöyle açıklar: "Erek yazın açısından bakıldığında her çeviri, kaynak metnin belli bir amaç için bir ölçüde yönlendirilmesini içerir (Hermans, 2014: 16).” Çevirmen, bu yönlendirmenin farkında olabilir ya da olmayabilir. Hatta yönlendirme, çevirmen ile büsbütün ilgisiz dahi olabilir. Lefevere (2014: 226), çeviri olgusunu bir yeniden yazma eylemi olarak betimlediği çalışmasında bu yönlendirmeleri, Even Zohar'ın çoğul dizge kuramı çerçevesinde "toplum olarak bilinen üstdizgeyi oluşturan dizgelerden biri" olarak tanımlanan erek yazın ile ilişkileri bağlamında inceler. 69 Lefevere (a.e: 225), yazının "gerekirci bir dizge olmayışının" altını çizer ve bir dizge olarak yazının okuru, yazarı ve yeniden yazarı (çevirmeni) kendisine bir dizi kısıtlamalarla bağladığını ifade eder. Bu kısıtlamaların çözümlenmesi, erek ekinde yazın çevirisini yönlendiren normların belirlenmesi için gereklidir. Lefevere (a.e: 226-227), yazın dizgesini yönlendiren kısıtlamaları iki öğeye ayırır. İlk öğeyi tercümanlar, eleştirmenler, yayımcılar, yazın öğretmenleri ve çevirmenler oluşturur. İkinci öğe, çoğunlukla yazın dizgesinin dışında işleyen ve Lefevere'in himaye (ing. patronage) olarak adlandırdığı 
"yazının yazımına, okunmasına ve yeniden yazımına yardım eden veya bunları engelleyen güçler" olarak tanımlanan öğedir. İlk öğe, yazın dizgesini ikinci öğe tarafından belirlenen değişkenlere göre içeriden yönlendirir: Belli yazınsal yapıtların erek dizgeye dahil edilmelerini dönemin toplumunda geçerli olan düşüngü ve yazın anlayışına aykırı düştükleri gerekçesiyle engelleyebilseler de bu yeniden yazarlar genellikle yapıtları dönemlerinin baskın sanatsal ve düşüngüsel anlayışına göre uyarlayarak erek dizgeye katarlar. Çalışmayı oluşturan çevirilerin tanıtıldı̆̆ 1 önceki bölümde değinilen 1984 eserinin çevirmeni Celâl Üster'in yapıtı yeniden çevirişine gerekçe olarak önceki “çevirinin eskimesini” gösterişi bu bağlamda yapıtı dönemin değişen koşullarına uyarlama girişimi olarak görülebilir. Lefevere'in (a.e: 227) yazın dizgesini ve dolayısıyla yazın çevirisini yönlendiren ikinci öğe olarak nitelendirdiği himaye, yazının sanatsal yönünden çok ideolojik yönüyle ilgilenir ve sanatsal bağlamda yetkiyi birinci öğeye devreder. İkinci öğenin yazının biçimi ve öznesinin seçiminde etkin olan ideolojik bileşkesinin yanı sıra birinci sınıfın ihtiyaçlarını karşılayan tecimsel bir bileşkesi ve bununla birlikte himayenin etrafında şekillenen zümre ya da alt kültür ile bütünleşmeyi şart koşan sınıfsal bir bileşkesi de vardır. Yönlendirmeci Okulu'nun çoğul dizgesel, betimleyici bakış açısını benimseyen Hermans (1996: 26), yazın çevirisinde çevirmenin görünürlüğü olgusunu çevirmenin söylemsel varlığ nitelendirmesiyle Rimmon-Kennan ve Chatman tarafından tanımlanan anlatımsal bildirişim modeline gönderme yaparak çözümler. Metni, biyografik yazar ve biyografik okur arasındaki bir bildirişim olarak tanıtlayan bu model, iletişim oluğunu biyografik yazardan metne giderken örtük yazar ve anlatıcı kavramları üzerinden, metinden biyografik okura giderken de anlatılan ve örtük okur kavramları üzerinden kurar. Hermans, anlatımsal bildirişim modelinin çeviri yazını bağlamında çeviri olgusunu göz ardı ederek yetersiz kaldığını savlar. Bir Dostoyevski çevirisini okurken alışılageldik "Dostoyevski okuyorum (Hermans, a.e: 26)" ifadesinin ilgili eserin çevirmenini büsbütün görmezden gelen bir yanılsama yarattığını ifade eden çeviribilimci, çeviri yazını metinlerinin hepsinde "çevirmenin sesi (Hermans, a.e: 27)" olarak nitelendirdiği ikincil bir sesin var olduğunu belirtir. Çevirmenin söylemsel varlığı, anlatıcının gölgesinde, tespit edilmesi zor ya da büsbütün tespit edilemez bir konumda kalabileceği gibi belli koşullarda gün yüzüne çıkarak belirgin bir duruma da gelebilir.

\section{Sonuç}

Distopya yazını çevirisi açısından varılan sonuçlar değerlendirildiğinde yazın türüne özgü iğneleyici, eleştirel söylemin çevirmen kararları ve çevirideki kaymalar üzerinde ideolojik ve ruhbilimsel bağlamda etkili olduğu görülmüştür. Çevirmenin kaynak metin yazarının yönelttiği toplum eleştirisiyle ideolojik bağlamda kurduğu ilişki çevirmenin görünmezliğiyle bir karşıtlık yaratarak çevirmeni, deyim yerindeyse, su yüzüne çıkmaya zorlamaktadır. Çeviri incelemelerinde bu tür karşıtlıkların varlığı çeviri eleştirmenleri ve araştırmacıları için verimli bir zemin oluşturur. Çevirmenin görünmezliği ile ideolojik söylem arasındaki karşıtlık, çevirmenin çeviri süreci boyunca aldığı bilinçli kararların ve çeviri sürecine hakim olan eğilimlerin 
saptanması ve anlamlandırılması açısından önemlidir. Dahası, bütünce temelli yaklaşım ile çevirilerin incelenmesi ve karşılaştırılması, küçük ölçekteki kararların ve kaymaların çeviri süreci boyunca çevirmenin ruhbilimsel bağlamda metin ile kurduğu ilişkilerin ve bilinçli olmadan verdiği kararların çözümlenmesine ve böylelikle bahsi geçen karşıtlığın ve benzeri karşıtlıkların çevirmen ve dolayısıyla çeviri metin üzerindeki ruhbilimsel etkilerinin bulgulanmasina olanak tanıyabilir.

\footnotetext{
Hakem Değerlendirmesi: Dış bağımsız.

Çıkar Çatışması: Yazarlar çıkar çatışması bildirmemiştir.

Finansal Destek: Yazarlar bu çalışma için finansal destek almadığını beyan etmiştir.

Peer-review: Externally peer-reviewed.

Conflict of Interest: The authors have no conflict of interest to declare.

Grant Support: The authors declared that this study has received no financial support.
}

\section{KAYNAKÇA/REFERENCES}

Bacon, F. (2011). Yeni Atlantis. (Çiğdem Dürüşken Çev.) (2. bs). İstanbul: Kabalcı Yayınevi.

Berk, Ö. (2005). Kuramlar ışı̆̆ında açıklamalı çeviribilim terimcesi (1. bs). İstanbul: Multilingual.

Bezel, N. (1984). Yeryüzü cennetleri kurmak: ütopyalardan seçmeler (1. bs). İstanbul: Say Yayınları.

Bezel, N. (1984). Yeryüzü cennetlerinin sonu: Distopyalar (1. bs). İstanbul: Say Yayınlar1.

Burdekin, K. S. (2015). Geceleri (Mehtap Gün Ayral Çev.) (3. bs). İstanbul: Encore Yayınları.

Çörekçioğlu, H. (2013). Modernite ve Ütopya: Ütopya, 1984 ve Mülksüzler Üzerinden (1. bs). İstanbul: Minval Yayınları.

Eco, U. (2013). Anlatı ormanlarında altı gezinti (Kemal Akatay Çev.) (7. bs). İstanbul: Can Yayınları.

Freud, S. (2011). Uygarlığın huzursuzluğu (Haluk Barışcan Çev.) (4. bs). İstanbul: Metis Yayınları.

Hermans, T. (1996). The translator's voice in translated narrative. Target: International Journal of Translation Studies, 8(1), 152.

Hermans, T. (2014). Introduction: translation studies and a new paradigm. In Theo Hermans (Eds.),

The Manipulation of Literature: Studies in Literary Translation (1. bs). A.B.D.: Routledge.

Huxley, A. (2011). Cesur yeni dünya (Ümit Tosun Çev.) (7. bs). İstanbul: İthaki Yayınları.

London, J. (2006). Demir ökçe. (Osman Çakmakçı Çev.) (9. bs). İstanbul: Bordo Siyah Yayınları.

Lefevere, A. (2014). Why waste our time on rewrites? The trouble with interpretation and the role of rewriting in an alternative paradigm. In The Hermans (Eds.), The Manipulation of Literature: Studies in Literary Translation (1. bs). A.B.D.: Routledge.

Mannheim, K. (2004). İdeoloji ve ütopya. Mehmet Okyayuz Çev.) (2.bs). Ankara: Epos Yayınları.

Mannheim, K. (2009). İdeoloji ve ütopya (Mehmet Okyayuz Çev.) (1. bs). Ankara: De Ki Basım Yayım Ltd. Şti. ISBN: 978-9944-492-39-3 153.

More, T. (2012). Ütopya. (Hasan İlhan Çev.) (1. bs). Ankara: Alter Yayıncılık.

More, T. (2012). Utopia (1. bs). İstanbul: Dejavu Publishing. 
More, T. (2012). Utopia (Sabahattin Eyüboğlu, Vedat Günyol ve Mîna Urgan Çev.) (1. bs). İstanbul: Türkiye İş Bankası Kültür Yayınları.

Orwell, G. (2008). Bin dokuz yüz seksen dört (Nuran Akgören Çev.) (19. bs). İstanbul: Can Yayınları.

Orwell, G. (2014). Bin dokuz yüz seksen dört (Celâl Üster Çev.) (42. bs). İstanbul: Can Yayınları.

Popper, K (1998). Açık toplum ve düşmanları, cilt 1: Platon. (Mete Tunçay Çev.) (3. bs). İstanbul: Remzi Kitabevi Schenider, G., \& Volk, M. (1998). Adding manual constraints and lexical lookup to a Brill-tagger for German. Proceedings of the ESSLLI-98 Workshop on Recent Advances in Corpus Annotation, Saarbrücken.

Nordic Conference of Computational Linguistics, Riga, 2011154 Somay, Bülent The View From the Masthead Journey Through Dystopia Towards an Open-Ended Utopia, 1. bsk., İstanbul, İstanbul Bilgi University Press, 2010

Stolze, R. (2013). Çeviri kuramları: Giriş (Dr. Emra Durukan Çev.) (1. bs). İstanbul: Değiş̧im Yayınları.

Swift, J. (2011). Güliver 'in gezileri (İrfan Şahinbaş Çev.) (4. bs). İstanbul: Türkiye İş Bankası Kültür Yayınları. Platon (2006). Devlet (Sabahattin Eyüboğlu ve M. Ali Cimcoz Çev.) (2. bs). İstanbul: Türkiye İş Bankası Kültür Yayınları.

Taylor, F. W. (2012). Bilimsel yönetimin ilkeleri (H. Bahadır Akın Çev.) (5. bs). Ankara: Adres Yayınları.

Üster, C. (2014). Elinizdeki Çeviriye İlişkin Bir Açıklama (Ek), George Orwell, Bin Dokuz Yüz Seksen Dört, Çev. Üster, 42. bsk., İstanbul: Can Yayınları.

Yazıc1, M. (2010). Çeviribilimin temel kavram ve kuramları (2. bs). İstanbul: Multilingual.

Wells, H. G. (2016). Zaman makinesi (Volkan Gürses Çev.) (3. bs). İstanbul: İthaki Yayınları.

Wells, H. G. (2016). A modern utopia. (Çevrimiçi), https: //ebooks.adelaide.edu.au/w/wells/hg/w45mu/w45mu. epub, 26 Nisan 2016

Wikipedia We (novel). (2016). (Çevrimiçi), https://en.wikipedia.org/wiki/We_(novel), 9 Mayıs 2016 Wikipedia Frederick Winston Taylor.

(Çevrimiçi), https://en. wikipedia.org/wiki/Frederick_Winslow_Taylor, 10 Mayıs 2016 Wikipedia Michael Walter (Übersetzer), 2016,

(Çevrimiçi), https://de. wikipedia.org/wiki/Michael_Walter_(\%C3\%9Cbersetzer), 23 Mayıs 2016

Wikipedia Oliver Cromwell (2016). (Çevrimiçi), https://tr.wikipedia. org/wiki/Oliver_Cromwell, 13 Haziran 2016

Wikipedia Oranges and Lemons, 2016, (Çevrimiçi), https://en. wikipedia.org/wiki/Oranges_and_Lemons, 14 Haziran 2016

Zamyatin, Y. (2012). Biz (Fatma Arıkan ve Serdar Arıkan Çev.) (1. bs). İstanbul: İthaki Yayınları. 
